Research article

\title{
Adenovirus type 5 E1A-induced apoptosis in COX-2-overexpressing breast cancer cells
}

\author{
Takeshi Sugimoto ${ }^{1,2}$, Chandra Bartholomeusz ${ }^{1,2}$, Ana M Tari ${ }^{3}$ and Naoto T Ueno ${ }^{1,2,4}$
}

\author{
${ }^{1}$ Breast Cancer Translational Research Laboratory, The University of Texas M. D. Anderson Cancer Center, Houston, TX, USA \\ 2Department of Stem Cell Transplantation and Cellular Therapy, The University of Texas M. D. Anderson Cancer Center, Houston, TX, USA \\ ${ }^{3}$ Department of Experimental Therapeutics, The University of Texas M. D. Anderson Cancer Center, Houston, TX, USA \\ ${ }^{4}$ Department of Breast Medical Oncology, The University of Texas M. D. Anderson Cancer Center, Houston, TX, USA \\ Corresponding author: Naoto T Ueno, nueno@mdanderson.org
}

Received: 7 Jul 2006 Revisions requested: 24 Aug 2006 Revisions received: 9 Jan 2007 Accepted: 5 Jul 2007 Published: 5 Jul 2007

Breast Cancer Research 2007, 9:R41 (doi:10.1186/bcr1739)

This article is online at: http://breast-cancer-research.com/content/9/4/R41

(C) 2007 Sugimoto et al.; licensee BioMed Central Ltd.

This is an open access article distributed under the terms of the Creative Commons Attribution License (http://creativecommons.org/licenses/by/2.0), which permits unrestricted use, distribution, and reproduction in any medium, provided the original work is properly cited.

\begin{abstract}
Introduction Suppression of Bcl-2 expression can overcome cellular resistance to apoptosis induced by the adenovirus type 5 gene $E 1 A$ in models of ovarian and breast cancer. Celecoxib, a cyclooxygenase-2 (COX-2) inhibitor, is known to downregulate $\mathrm{Bcl}-2$ expression. We hypothesized that celecoxib would enhance E1A-induced apoptosis by suppressing $\mathrm{Bcl}-2$ through suppressing COX-2 expression. If successful, this strategy could represent a means of overcoming resistance to $E 1 A$ gene therapy.

Methods We first established the cytotoxicity of celecoxib in two COX-2-overexpressing E1A-transfected breast cancer cell lines (MDA-MB-231 and MDA-MB-435) and in two low-COX-2expressing E1A-transfected cell lines (MCF-7 (breast cancer) and SKOV3.ip1 (ovarian cancer)). We next tested whether higher sensitivity to celecoxib among these cell lines resulted from increased apoptosis by flow cytometry and western blotting. We further investigated whether suppression of Bcl-2 by celecoxib was involved in the apoptosis resulting from celecoxib treatment, and we explored whether the celecoxibinduced apoptosis in these cells depends on a COX-2 downstream pathway.
\end{abstract}

Results The two COX-2-overexpressing cell lines MDA-MB231-E1A and MDA-MB-435-E1A were more sensitive to celecoxib than the corresponding control cells, but the two lowCOX-2-expressing cell lines MCF-7-E1A and SKOV3.ip1-E1A were no more sensitive than control cells to celecoxib. Therefore, we used the MDA-MB-231-E1A and MDA-MB-435$E 1 A$ cells for all further experiments. In both cell lines, sub- $G_{1}$ fraction was increased, or cleavage of PARP and caspase- 9 were increased after 5 days of exposure to $40 \mu \mathrm{M}$ celecoxib. However, Bcl-2 was suppressed only in the MDA-MB-435-E1A cells and not in the MDA-MB-231-E1A cells. Restoring Bcl-2 expression in the MDA-MB-435-E1A stable transfectants did not affect their sensitivity to celecoxib. However, adding prostaglandin $\mathrm{E}_{2}\left(\mathrm{PGE}_{2}\right)$ or $\mathrm{PGF}_{2 \alpha}$ blunted the sensitivity to celecoxib of both $E 1 A$ stable transfectants.

Conclusion We speculate that one mechanism by which celecoxib enhances $E 1 A$-induced apoptosis in cells that express high levels of COX-2 is through blocking $\mathrm{PGE}_{2}$ or $\mathrm{PGF}_{2 \alpha}$.

\section{Introduction}

The adenovirus type 5 gene $E 1 A$ is being developed as a therapeutic agent for breast, head and neck, and ovarian cancer [1-3]. The tumor-suppressive effect of E1A results from its induction of apoptosis, its inhibition of invasion and metastasis, and its suppression of proliferation [4]. Although the mechanism by which $E 1 A$ induces apoptosis is not completely understood, accumulating evidence suggests that $E 1 A$ exerts its apoptotic effect through several pathways. One such pathway involves binding of E1A to the retinoblastoma protein, which results in the release and activation of transcription factor E2F [4-6]. Activated E2F can induce apoptosis through p53-dependent and p53-independent pathways [7-9]. E1A is also known to induce apoptosis through p53-dependent and p53-independent pathways [10]. Several factors that modulate $E 1 A$-induced apoptosis have been reported, including

COX-2 = cyclooxygenase-2; DMEM/F12 = Dulbecco's modified Eagle's medium/Ham's F-12 medium; E1A = adenovirus type 5 gene E1A; MTT = 3-(4,5-dimethylthiazol-2-yl)-2,5-diphenyltetrazolium bromide; PARP = poly ADP-ribosome polymerase; PBS = phosphate-buffered saline; PGE $2=$ prostaglandin $\mathrm{E}_{2} ; \mathrm{PGF}_{2 \alpha}=$ prostaglandin $\mathrm{F} 2 \alpha ; \mathrm{TNF}-\alpha=$ tumor necrosis factor- $\alpha$; TRAIL = TNF-related apoptosis-inducing ligand. 
tumor necrosis factor $\alpha$ (TNF- $\alpha$ ) [11,12], TNF-related apoptosis-inducing ligand (TRAIL) [13] or TRAIL accompanied by caspase activation [14], activation of the pro-apoptotic factor p38 or inactivation of Akt/PKB [15], inhibition of nuclear factor-kappa B [16], and suppression of the Axl-Gas6 interaction [17].

However, E1A does not induce apoptosis efficiently in all types of cancer cells. The reason for this is unclear but could reflect the existence of a resistance mechanism or the oncogenic effects of the E1A gene. We recently showed that resistance to $E 1 A$ gene therapy in an ovarian cancer xenograft model could be overcome by downregulating $\mathrm{Bcl}-2$ with a Bcl2 antisense oligonucleotide [18]. Bcl-2 inhibits apoptosis by inhibiting the release of cytochrome $\mathrm{C}$ and the activation of caspase-9 in E1A-transfected cells. Bcl-2 was the only major mechanism blocking E1A-induced apoptosis in our previous model. Theoretically, a means of downregulating Bcl-2 would overcome resistance to the apoptosis induced by E1A gene therapy. Because the US Food and Drug Administration has yet to approve $\mathrm{Bcl}-2$ antisense oligonucleotide for clinical use, we are exploring other drugs that can also downregulate Bcl2. Recent reports that cyclooxygenase-2 (COX-2) inhibitors could induce apoptosis through $\mathrm{Bcl}-2$ downregulation led us to consider the role of COX-2 inhibitors in the E1A-induced apoptosis of cancer cells. In those reports, the selective COX2 inhibitor NS-398 was found to downregulate $\mathrm{Bcl}-2$ in LNCaP prostate cancer cells [19]; another COX-2 inhibitor, celecoxib, downregulated $\mathrm{Bcl}-2$ in $\mathrm{K} 562$ chronic myeloid leukemia cells [20] and in MPP89 malignant mesothelioma cells [21]. In vivo investigations have shown that $\mathrm{Bcl}-2$ downregulation by COX-2 inhibitors is accompanied by downregulation of the COX-2 protein. In one study of mice implanted with the hepatoma cell line $\mathrm{H} 22$, treatment with the COX-2 inhibitor nimesulide led to reductions in both COX-2 and Bcl2 expression [22]. Similarly, celecoxib also reduced both COX-2 and Bcl-2 expression in an MTag mouse model of breast cancer [23]. Conversely, another group has proposed that COX-2 overexpression increases resistance to apoptosis through the upregulation of $\mathrm{Bcl}-2$ [24]. Still others have shown that forced COX-2 overexpression or treatment with prostaglandins induces $\mathrm{Bcl}-2$ expression $[25,26]$. Collectively, these reports suggest that COX-2 is upstream of $\mathrm{Bcl}-2$ and led us to propose that suppressing COX-2 expression with the COX-2 inhibitor celecoxib will suppress $\mathrm{Bcl}-2$ expression, thereby enhancing $E 1 A$-induced apoptosis. If successful, this strategy could represent a means of overcoming resistance to $E 1 A$ gene therapy.

\section{Materials and methods Cell lines and reagents}

Three human breast cancer cell lines (MDA-MB-231, MDAMB-435, and MCF-7) and one ovarian cancer cell line (SKOV3.ip1, a subline of SKOV3 cells) were maintained in Dulbecco's modified Eagle's medium/Ham's F-12 medium
(DMEM/F12; Gibco-BRL, Grand Island, NY, USA) supplemented with $10 \%$ fetal bovine serum and penicillin/streptomycin, and maintained in a humidified atmosphere of $5 \% \mathrm{CO}_{2}$ at $37^{\circ} \mathrm{C}$. The parental cell lines, the vector only transfection control cells, and the E1A-transfected cells were all kindly provided by Dr Mien-Chie Hung (The University of Texas M D Anderson Cancer Center, Houston, TX, USA) $[15,27,28]$. The E1A stable transfectants were selected by growing them in DMEM/F12 medium containing $500 \mu \mathrm{g} / \mathrm{ml} \mathrm{G} 418$. All experiments were conducted under the guidelines of the M D Anderson Cancer Center.

Celecoxib (LKT Laboratories, St Paul, MN, USA) was dissolved in dimethylsulfoxide to $100 \mathrm{mM}$ and stored at $-20^{\circ} \mathrm{C}$. For the cell culture experiments, celecoxib was diluted with $\mathrm{DMEM} / \mathrm{F} 12$ in various concentrations. The final concentration of dimethylsulfoxide in the DMEM/F12 medium was kept at less than $0.1 \%$. PGE 2 and $\mathrm{PGF}_{2 \alpha}$ (Cayman Chemical, Ann Arbor, MI, USA) were dissolved in dimethlysulfoxide to $10 \mathrm{mM}$ and stored at $-20^{\circ} \mathrm{C}$.

\section{Cell viability assays}

Cell viability was assessed with 3-(4,5-dimethylthiazol-2-yl)2,5-diphenyltetrazolium bromide (MTT) [29] and trypan blue exclusion assays. For the MTT assay, cells were plated in 96well plates $\left(1.2 \times 10^{4}\right.$ cells/well for MDA-MB-231 cells or 8.0 $\times 10^{3}$ cells/well for MDA-MB-435, MCF-7, and SKOV3.ip1 cells) in $80 \mu \mathrm{l}$ of medium and incubated for $24 \mathrm{~h}$. Then, $20 \mu \mathrm{l}$ of fresh medium containing celecoxib at $0-300 \mu \mathrm{M}$ were added to each well, resulting in final celecoxib concentrations of 0-60 $\mu \mathrm{M}$ in five sequential dilutions. After cells had been cultured with celecoxib for 3 or 5 days, MTT (Sigma Chemical Co., St Louis, MO, USA) was added to a final concentration of $1 \mathrm{mg} / \mathrm{ml}$. Reaction mixtures were incubated for $3 \mathrm{~h}$. The resulting crystals were dissolved in dimethlysulfoxide $(200 \mu \mathrm{l})$, and optical density was measured at $570 \mathrm{~nm}$ with a microplate reader (Bio-Rad Laboratories, Hercules, CA, USA).

We also used a trypan blue exclusion assay to confirm cell viability during treatment with $40 \mu \mathrm{M}$ celecoxib, because the viability varied greatly among cell types. For that assay, MDA-MB231 cells $\left(4 \times 10^{5}\right)$ or MDA-MB-435 cells $\left(2 \times 10^{5}\right)$ were plated in six-well plates in $2 \mathrm{ml}$ of DMEM/F12 and incubated for $24 \mathrm{~h}$. Then, $500 \mu \mathrm{l}$ of fresh medium containing $200 \mu \mathrm{M}$ celecoxib was added to each well, resulting in a final concentration of $40 \mu \mathrm{M}$, and the cells were incubated for 5 days. To determine the effect of $\mathrm{PGE}_{2}$ or $\mathrm{PGF}_{2 \alpha}$ on celecoxib sensitivity, exogenous $\mathrm{PGE}_{2}$ or $\mathrm{PGF}_{2 \alpha}(10 \mu \mathrm{M})$ was added to the celecoxib solution. After being cultured with celecoxib in the presence or absence of $\mathrm{PGE}_{2}$ or $\mathrm{PGF}_{2 \alpha}$ for 5 days, cells were harvested by trypsinization and incubated with $0.4 \%$ trypan blue (Sigma). Cell viability was calculated as the percentage of viable (nonstaining) cells. 


\section{Flow cytometry}

For flow-cytometric analysis of apoptosis, cells were harvested by trypsinization, washed twice with ice-cold PBS, and fixed with cold $70 \%$ ethanol at $-20^{\circ} \mathrm{C}$ overnight. The fixed cells were washed twice with PBS and suspended in $1 \mathrm{ml}$ of PBS containing Tween-20 (0.5\%), RNase $(10 \mu \mathrm{g} / \mathrm{ml})$, and propidium iodide $(10 \mu \mathrm{g} / \mathrm{ml})$. The sub- $\mathrm{G}_{1}$ (apoptotic) cell population was measured with a FACScan cytofluorometer (Becton Dickinson, San Jose, CA, USA).

\section{Western blotting}

For western blot analyses, cells were washed with PBS and lysed in lysis buffer $\left(20 \mathrm{mM} \mathrm{Na}_{2} \mathrm{PO}_{4}, 150 \mathrm{mM} \mathrm{NaCl}, 1 \%\right.$ Triton $\mathrm{X}-100,1 \%$ aprotinin, $1 \mathrm{mM}$ phenylmethylsulfonyl fluoride, 100 $\mathrm{mM} \mathrm{NaF}$, and $2 \mathrm{mM} \mathrm{Na}_{3} \mathrm{VO}_{4}$ ) as described previously [18]. Proteins were separated by polyacrylamide gel electrophoresis on a sodium dodecyl sulfate-polyacrylamide gel and transferred to a polyvinylidene difluoride membrane (Bio-Rad). Membranes were incubated with primary antibodies specific for COX-2 (1:1000; Cayman Chemical); Bcl-2 (1:500) and E1A (1:500) (both from BD PharMingen); poly-ADP ribosome polymerase (PARP) $(1: 1000)$ and cleaved caspase-9 $(1: 200)$ (both from Cell Signaling Technology, Beverly, MA, USA); caspase-8 (1:200) (from Oncogene Research Products, San Diego, CA, USA); and actin (1:5000) (Sigma). Then, membranes were incubated with fluorescent-conjugated mouse $(1: 5000)$ or rabbit $(1: 5000)$ secondary antibodies (IRdye; LiCor Biosciences, Lincoln, NE, USA). The membranes were scanned and relative protein expression levels estimated by using an Odyssey western blotting system (Li-Cor Biosciences). Downregulation was defined as a protein expression level at least $20 \%$ less than that of the control (untreated) cells.

\section{Bcl-2 transfections}

The Bcl-2 expression vector was constructed by inserting Bcl2 cDNA at the EcoRI site of the pCl-neo mammalian expression vector (Promega, Madison, WI, USA). Briefly, MDA-MB435 cells $\left(4 \times 10^{5}\right)$ were cultured for $24 \mathrm{~h}$ in six-well plates in $1 \mathrm{ml} /$ well of DMEM/F12 with $10 \%$ fetal bovine serum until $60-$ $70 \%$ confluence. The next day, the liposomal vector of the SN gene delivery system [30] was incubated with Bcl-2 DNA at a ratio of $4 \mu \mathrm{g}$ DNA: $5 \mu \mathrm{lSN}$ in $100 \mu \mathrm{l}$ Opti-MEM in each well and added to the cultures. Bcl-2-overexpressing cells and control cells were plated $24 \mathrm{~h}$ later and tested for viability with a trypan blue exclusion assay as described above.

\section{Prostaglandin analyses}

MDA-MB-231-E1A cells $\left(4 \times 10^{5}\right)$ or MDA-MB-435- $E 1 A$ cells $\left(2 \times 10^{5}\right)$ were plated in six-well plates in $2 \mathrm{ml}$ of DMEM/F12, incubated for $24 \mathrm{~h}$, and treated with celecoxib $(0-40 \mu \mathrm{M})$ for $120 \mathrm{~h}$. At that time, cellular supernatants were collected and analyzed for $\mathrm{PGE}_{2}$ and $\mathrm{PGF}_{2 \alpha}$ by enzyme-linked immunosorbent assay (Cayman Chemical) according to the manufacturer's instructions.

\section{Statistical analyses}

Two-tailed paired $t$-tests were used to compare data between groups. $P<0.05$ was considered to be statistically significant. Data were expressed as means $\pm S D$ of at least three independent experiments, each of which was run in quadruplicate.

\section{Results \\ COX-2 expression in E1A-transfected breast and ovarian cancer cell lines}

We first investigated the expression of COX-2 protein in three breast cancer cell lines (MDA-MB-231, MDA-MB-435, and MCF-7) and an ovarian cancer cell line (SKOV3.ip1), all stably transfected with $E 1 A$, to determine the relationship between COX-2 protein expression level and sensitivity to celecoxib. Western blot analyses showed that COX-2 expression was highest in the MDA-MB-231-E1A transfectants, followed closely by the MDA-MB-435-E1A transfectants. By contrast, COX-2 expression was low in the SKOV3.ip1-E1A and MCF7-E1A transfectants (Figure $1 \mathrm{~A}$ ). If the COX-2 expression level of the MDA-MB-231-E1A stable transfectants is considered to be $100 \%$, the relative percentage COX-2 expression for each stable transfectant is as follows: MDA-MB-435-E1A, 78\%; SKOV3.ip1-E1A, 6\%; and MCF-7-E1A, 6\%. Thus, we defined MDA-MB-231-E1A and MDA-MB-435-E1A stable transfectants as high-COX-2-expressing cell lines, and SKOV3.ip1-E1A and MCF-7-E1A stable transfectants as lowCOX-2-expressing cell lines.

To rule out the possibility that $E 1 A$ transfection affects $C O X$ 2 expression levels, we compared COX-2 levels in E1A stable transfectants with that in the corresponding vector control cells by western blotting analysis. If the COX-2 expression levels of each E1A transfectant is defined as $100 \%$, the corresponding COX-2 expression levels of the vector controls were as follows: $65 \%$ for MDA-MB-231, 144\% for MDA-MB-435, $71 \%$ for SKOV3.ip1 and $67 \%$ for MCF-7 (Figure 1B). Thus, we found that $E 1 A$ transfection did not consistently affect COX-2 expression levels in these cell lines.

\section{Celecoxib induces apoptosis in MDA-MB-231-E1A and MDA-MB-435-E1A stable transfectants}

After establishing the relative amounts of COX-2 protein expressed by the $E 1 A$ stable transfectants, we investigated whether those transfectants were more sensitive to celecoxib than their respective controls by using an MTT assay. The high-COX-2-expressing MDA-MB-231-E1A and MDA-MB435- $E 1 A$ cells were more sensitive to celecoxib (after 5 days of exposure to $0-60 \mu \mathrm{M}$ ) than the vector control or parental control cells (Figure 2A). By contrast, the low-COX-2-expressing cells (SKOV3.ip1 and MCF-7) showed no difference in celecoxib sensitivity between the $E 1 A$ transfectants and the controls (Figure 2B).

To quantitatively compare differences in sensitivity to celecoxib among cells, we tested the MDA-MB-231-E1A and 
Figure 1
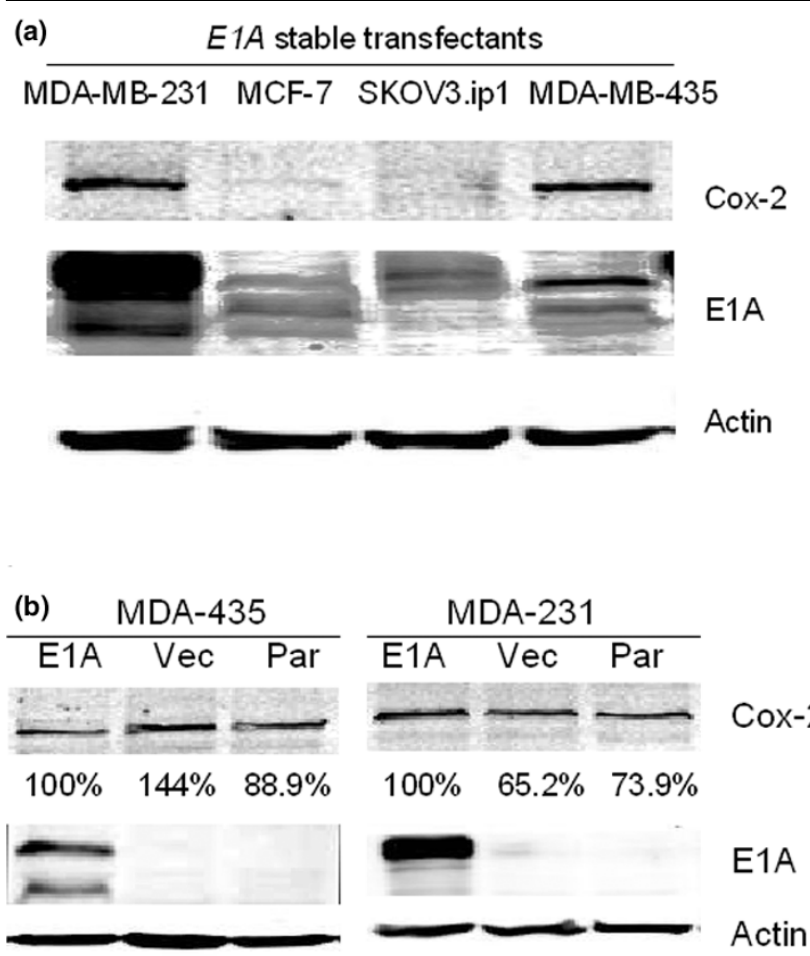

Cox-2
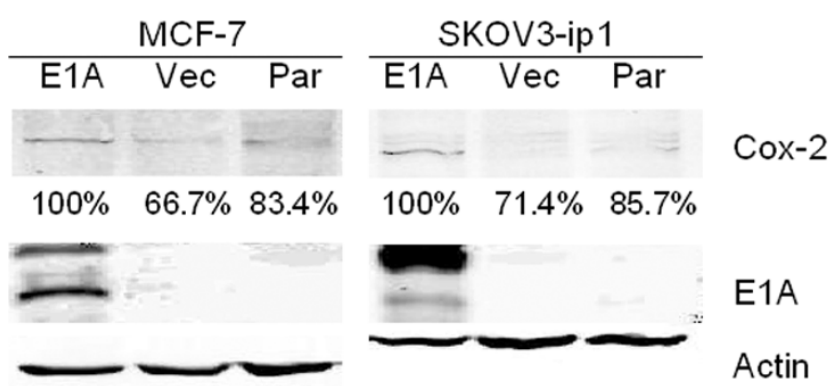

COX-2 protein expression in breast and ovarian cancer cell lines stably transfected with E1A. (a) MDA-MB-231-E1A stable transfectants produced the greatest amounts of COX-2; MDA-MB-435-E1A cells produced $78 \%$ of that amount, but the SKOV3.ip1-E1A and MCF-7-E1A cells produced only $6 \%$ of that amount. MDA-MB-231-E1A cells expressed slightly more E1A than the other three cell lines. (a) COX-2 protein expression level between the $E 1 A$ stable transfectants and their corresponding vector control cells or parent cells. If the COX-2 expression levels of each E1A transfectant is defined as $100 \%$, the corresponding COX-2 expression levels of the vector controls were as follows: $65 \%$ for MDA-MB-231, 144\% for MDA-MB-435, 71\% for SKOV3.ip1 and 67\% for MCF-7.

MDA-MB-435-E1A transfectants and their controls with a trypan blue assay. After a 5-day exposure to $40 \mu \mathrm{M}$ celecoxib, the MDA-MB-231-E1A cells were significantly more sensitive (mean 23.8\% \pm SD 2.2\% viable cells) than the MDA-MB-231 vector control cells $(82.3 \% \pm 3.9 \%)(P=0.0002)$ or the MDAMB-231 parental cells $(82.0 \% \pm 1.4 \%)(P<0.0001)$. Similarly, the MDA-MB-435-E1A stable transfectants were more sensitive to celecoxib $(27.2 \% \pm 1.2 \%$ viable cells $)$ than the
MDA-MB-435 vector control cells $(91.2 \% \pm 0.5 \%)(P<$ $0.0001)$ or the MDA-MB-435 parental cells $(93.9 \% \pm 3.5 \%)$ $(P<0.0001)$ (Figure 2C). We then investigated whether these differences in viability had been caused by apoptosis by using flow cytometry. A 5-day exposure to $40 \mu \mathrm{M}$ celecoxib increased the sub- $\mathrm{G}_{1}$ fraction from $9.1 \%$ to $25.7 \%$ in MDAMB-231-E1A cells and from $8.2 \%$ to $37.1 \%$ in MDA-MB-435$E 1 A$ cells (Figure $3 A$ ), indicating increases in apoptosis. We also tested cleavage of PARP, caspase-8, and caspase- 9 as other indicators of apoptosis. Celecoxib treatment led to the disappearance of uncleaved PARP (116 kDa) in both cell lines; it also led to the appearance of cleaved PARP (89 kDa) in MDA-MB-435-E1A cells and the appearance of cleaved PARP expression in MDA-MB-231-E1A cells (Figure 3B). Celecoxib treatment also led to increases in cleaved caspase$9(37 \mathrm{kDa})$ levels in both MDA-MB-231-E1A and MDA-MB435- $E 1 A$ transfectants but did not affect levels of cleaved caspase-8 $(28 \mathrm{kDa})$. These results suggest that celecoxib treatment $(5$ days at $40 \mu \mathrm{M})$ induced apoptosis in MDA-MB-231 and MDA-MB-435 cells stably transfected with E1A.

\section{Celecoxib downregulates COX-2 protein expression in MDA-MB-231 and MDA-MB-435 cells}

Evidence that nonsteroidal anti-inflammatory drugs can suppress COX-2 by transcriptional regulation [31] as well as suppressing both COX-2 and Bcl-2 protein expression [22,23] led us to investigate whether celecoxib would change the amount of COX-2 protein expressed by MDA-MB-231 and MDA-MB-435 cells. Indeed, COX-2 protein expression was downregulated in all MDA-MB-231 cell variants; the percentage decreases were $32 \%$ for the MDA-MB-231 parental cells, $34 \%$ for the vector control cells, and $58 \%$ for the $E 1 A$ stable transfectants (Figure 4A). COX-2 protein expression was also decreased in all MDA-MB-435 variants, with the percentages being 39\% for MDA-MB-435 parental cells, 25\% for the vector control cells, and $60 \%$ for the E1A stable transfectants (Figure 4A). In both MDA-MB-231 and MDA-MB-435 cells, COX-2 was suppressed to a greater extent in the $E 1 A$ transfectants than in the corresponding parental or vector control cells. These results suggest that celecoxib-induced apoptosis in cells expressing $\mathrm{E} 1 \mathrm{~A}$ involves the suppression of COX-2.

\section{Bcl-2 suppression does not contribute to celecoxib- induced apoptosis in E1A stable transfectants}

Next, we investigated whether suppression of $\mathrm{Bcl}-2$ by celecoxib is involved in the apoptosis resulting from celecoxib treatment. After a 5-day treatment with $40 \mu \mathrm{M}$ celecoxib, Bcl2 levels in the MDA-MB-435 cells were decreased (by 27\%) only in the $E 1 A$ transfectant; $\mathrm{Bcl}-2$ level did not change in any of the MDA-MB-231 variants (Figure 4A). In timecourse experiments with the same celecoxib concentration $(40 \mu \mathrm{M}), \mathrm{Bcl}-2$ was suppressed by $37 \%$ at $72 \mathrm{~h}$ and by $52 \%$ at $96 \mathrm{~h}$ in MDAMB-435-E1A cells. However, Bcl-2 was not suppressed at either measurement time in the MDA-MB-231-E1A cells (Figure 4B). 

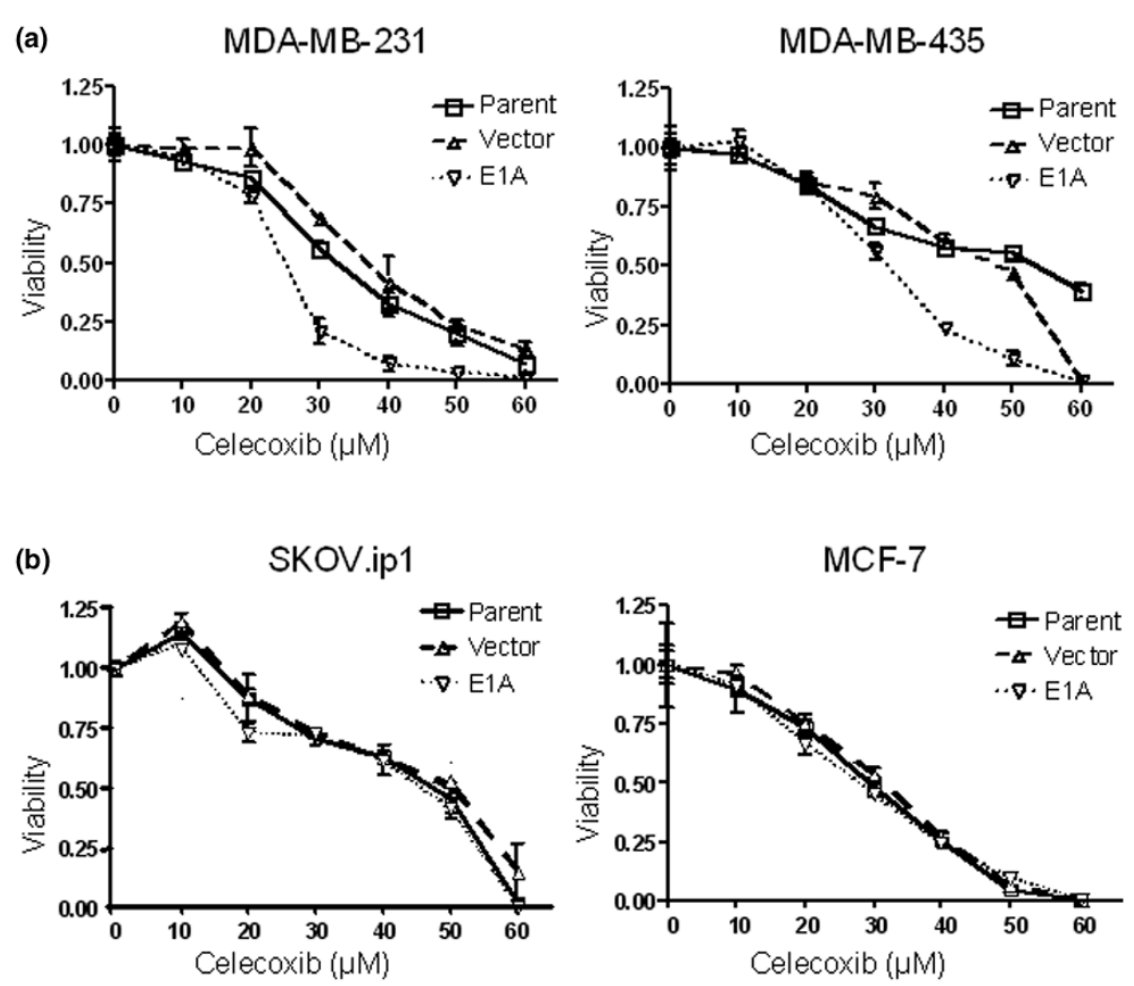

(c)
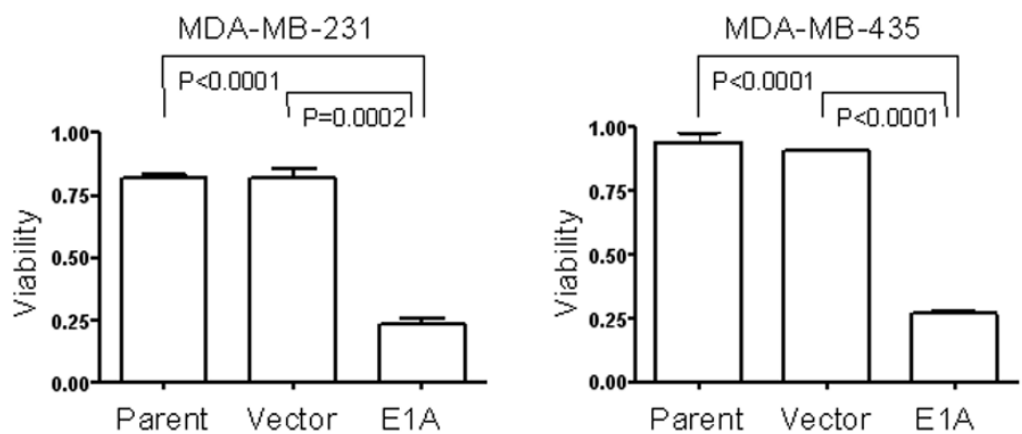

Celecoxib decreases the viability of MDA-MB-231-E1A and MDA-MB-435-E1A stable transfectants. (b) MTT assays after a 5-day exposure to 0-60 $\mu \mathrm{M}$ celecoxib indicate substantial reductions in cell viability in all variants of the MDA-MB-231 and MDA-MB-435 cell lines (E1A stable transfectants, vector control, and parental control cells). Each point represents means from tests performed in quadruplicate; the bars are standard deviations. In both cell lines, the $E 1 A$ transfectants were more sensitive than the vector control or parental control cells. (b) MTT assays in all variants of the SKOV3.ip1 and MCF-7 cell lines. The E1A transfectants have no difference to sensitivity for celecoxib in both cell lines. (c) Trypan blue assays after a 5-day exposure to $40 \mu \mathrm{M}$ celecoxib show substantial reductions in viability of MDA-MB-231 and MDA-MB-435 cells. Values shown are normalized to the viability of the control (untreated) cells. Each bar represents means from tests performed in quadruplicate; bars are standard deviations. $P$ values are from two-tailed paired $t$ tests.

As a further step in determining the contribution of Bcl-2 suppression to celecoxib-induced apoptosis, we transfected $\mathrm{Bcl}$ 2 DNA into the MDA-MB-435 variants (Figure 4C) to see if restoring $\mathrm{Bcl}-2$ expression would affect sensitivity to celecoxib. Bcl-2 restoration did not affect the viability of MDAMB-435-E1A stable transfectants after a 5-day treatment with $40 \mu \mathrm{M}$ celecoxib (Figure 4D). These results suggest that celecoxib induces apoptosis in MDA-MB-231-E1A and MDA-
MB-435-E1A stable transfectants regardless of $\mathrm{Bcl}-2$ expression.

\section{Celecoxib enhances apoptosis of MDA-MB-231-E1A and} MDA-MB-435-E1A cells via prostaglandins $E_{\mathbf{2}}$ or $F_{\mathbf{2} \alpha}$

Given our findings that celecoxib induced apoptosis in the E1A stable transfectants and that COX-2 downregulation is involved in this apoptosis but $\mathrm{Bcl}-2$ suppression is not, we next 
Figure 3

(a)
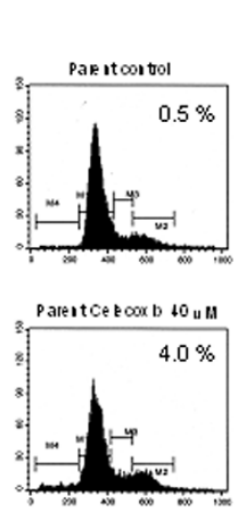

MDA-MB-231
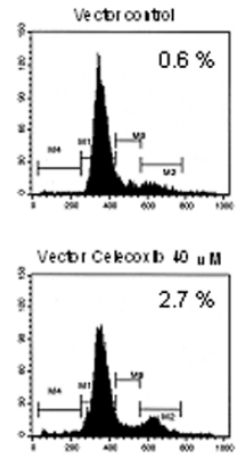

MDA-MB-435
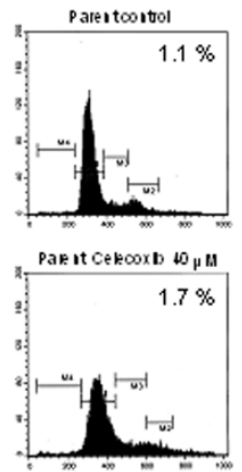

vector cortol
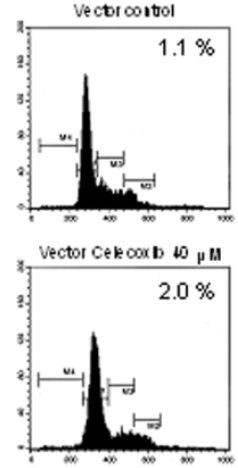

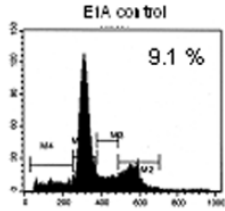

EIA CekOox b to uII
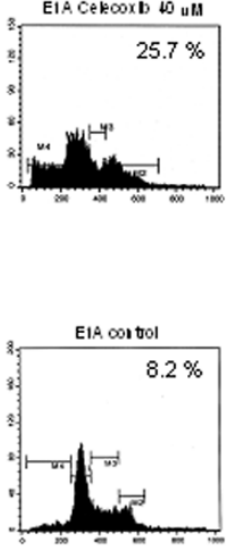

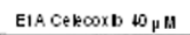

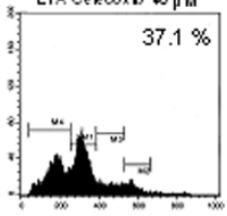

(b)

MDA-MB-231

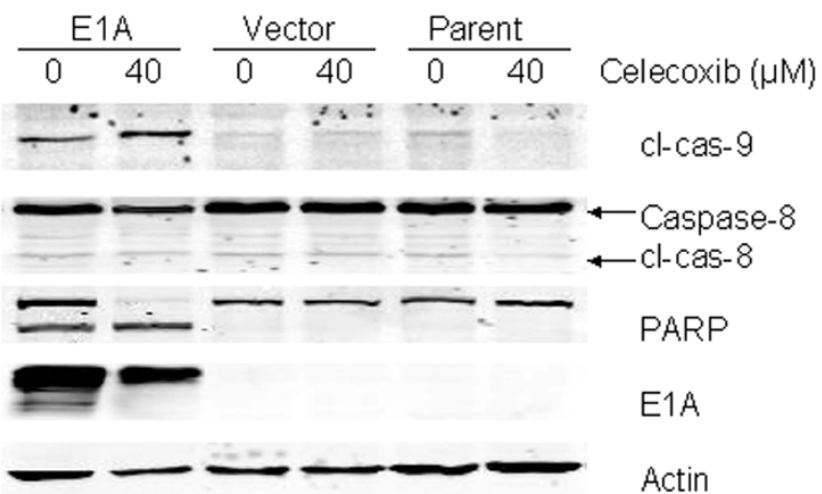

MDA-MB-435

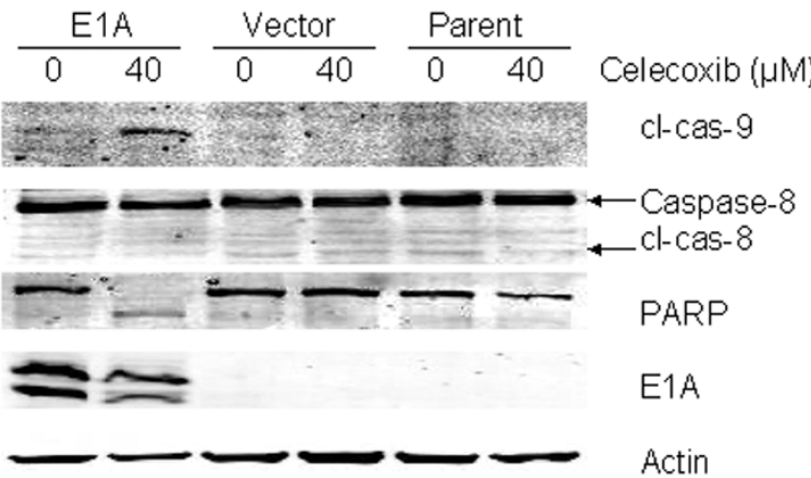

Celecoxib enhances apoptosis of MDA-MB-231-E1A and MDA-MB-435-E1A stable transfectants. (a) Cell cycle distribution of MDA-MB-231-E1A and MDA-MB-435-E1A cells was detected by fluorescence-activated cell sorting after a 5-day exposure to 0 or $40 \mu \mathrm{M}$ celecoxib. The percentage of cells in sub-G ${ }_{1}$ (apoptosis) appears at the upper right of each graph. (b) Western blots of MDA-MB-231 and MDA-MB-435 cells treated with 0 or $40 \mu \mathrm{M}$ celecoxib for 5 days and tested for cleaved caspase-9 (cl-cas-9), uncleaved and cleaved caspase-8 (cl-cas-8), PARP (uncleaved and cleaved), E1A, and actin. Cleaved PARP and cleaved caspase-9 levels were higher after celecoxib treatment in the MDA-MB-231-E1A and MDAMB-435-E1A stable transfectants, but expression of cleaved caspase-8 (cl-cas-8) did not change.

explored whether the celecoxib-induced apoptosis in these cells depends on a pathway downstream of COX-2. For these experiments, we tested the effects of a 5-day treatment with $40 \mu \mathrm{M}$ celecoxib on cell viability with or without the addition of $10 \mu \mathrm{M}$ prostaglandin (PG) $\mathrm{E}_{2}$ or $\mathrm{PGF}_{2 \alpha}$, two molecules located downstream of COX-2. In the MDA-MB-231-E1A cells, treatment with celecoxib alone produced a mean of $35.9 \%$ viable cells ( $\pm 2.7 \% \mathrm{SD}$ ); the addition of either prostaglandin substantially improved cell viability $(62.1 \% \pm$ $3.9 \%$ viable cells for $\mathrm{PGE}_{2}(P=0.0005), 63.0 \% \pm 3.8 \%$ for $\mathrm{PGF}_{2 \alpha}(P=0.0026)$. Results were similar for the MDA-MB435- $E 1 A$ cells $(33.3 \% \pm 7.5 \%$ for celecoxib only, $58.6 \% \pm$ $7.7 \%$ for $\mathrm{PGE}_{2}(P=0.041)$, and $60.2 \% \pm 6.7 \%$ for $\mathrm{PGF}_{2 \alpha}(P$ $=0.0030)$ ) (Figure 5 ). These results suggest that celecoxib enhances apoptosis of cells that stably express $E 1 A$ in part by blocking $\mathrm{PGE}_{2}$ or $\mathrm{PGF}_{2 \alpha}$.

To test the effect of celecoxib on prostaglandin synthesis, we assessed $\mathrm{PGE}_{2}$ and $\mathrm{PGF}_{2 \alpha}$ levels in MDA-MB-231-E1A and
MDA-MB-435-E1A cells treated for 5 days with $40 \mu \mathrm{M}$ celecoxib (data not shown). Enzyme-linked immunosorbent assay showed that in the MDA-MB-231-E1A cells, celecoxib treatment significantly inhibited $\mathrm{PGE}_{2}$ (mean $\pm \mathrm{SD} 0.20 \mathrm{pg} / \mathrm{ml}$ $\pm 0.08 \mathrm{pg} / \mathrm{ml}$ vs $2.16 \mathrm{pg} / \mathrm{ml} \pm 1.25 \mathrm{pg} / \mathrm{ml}$ for dimethylsulfoxide control; $P=0.002$ ), but celecoxib had no effect on $\mathrm{PGE}_{2}$ synthesis in the MDA-MB-435-E1A cells. Conversely, celecoxib inhibited PGF $_{2 \alpha}$ in MDA-MB-435-E1A cells $(121.7 \mathrm{pg} / \mathrm{ml} \pm$ $12.3 \mathrm{pg} / \mathrm{ml}$ vs $173.6 \mathrm{pg} / \mathrm{ml} \pm 7.4 \mathrm{pg} / \mathrm{ml}$ for control, $P=0.003$ ) but did not affect PGF ${ }_{2 \alpha}$ synthesis in MDA-MB-231-E1A cells.

\section{Discussion}

Our hypothesis was that celecoxib would enhance E1Ainduced apoptosis by suppressing COX-2 expression and thereby suppressing $\mathrm{Bcl}-2$ expression. In exploring the possibility that the COX-2 inhibitor celecoxib would downregulate $\mathrm{Bcl}-2$, we found that celecoxib did enhance $E 1 A$-induced apoptosis in cells that express high levels of COX-2 protein. We also found that $\mathrm{PGE}_{2}$ or $\mathrm{PGF}_{2 \alpha}$ are involved in this 
(a)

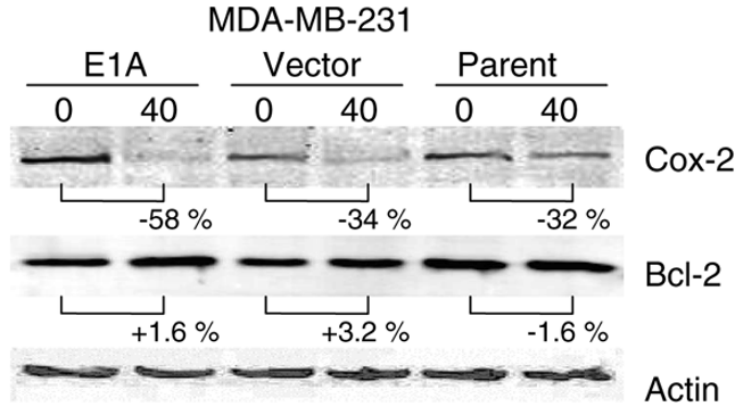

MDA-MB-435

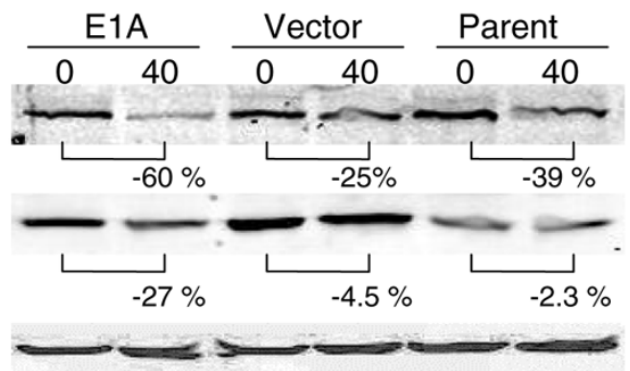

Cox-2

$\mathrm{Bcl}-2$

Actin

(b)

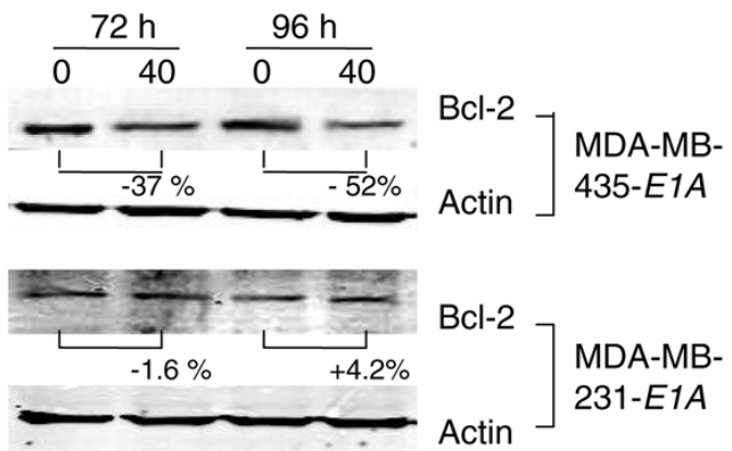

(c)

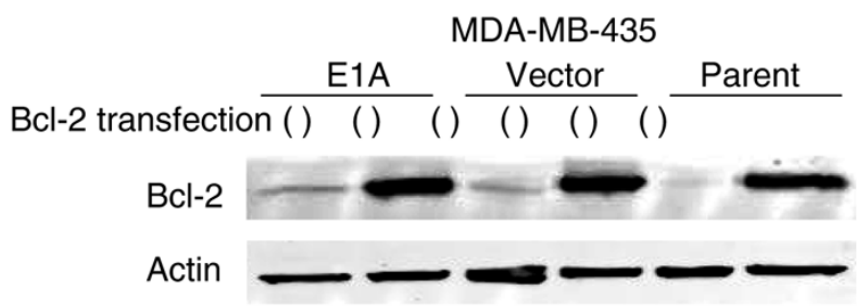

(d)

MDA-MB-435-E1A

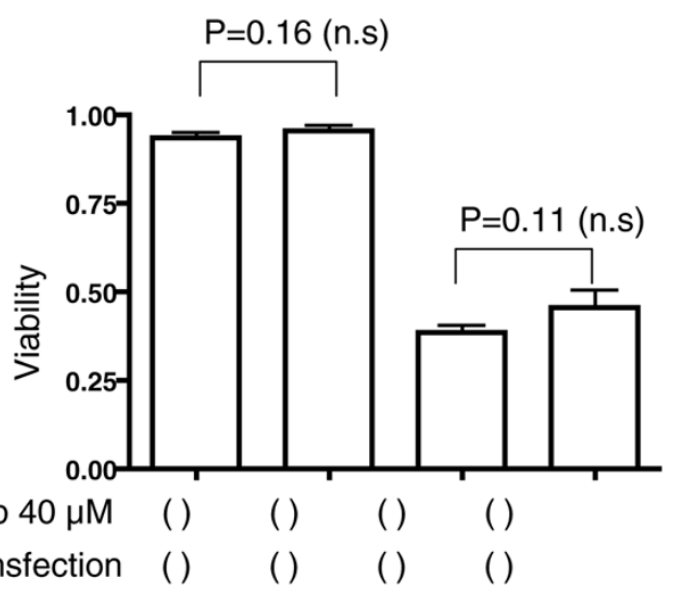

Celecoxib downregulated COX-2 protein expression in all MDA-MB-231 and MDA-MB-435 variants, but celecoxib downregulated Bcl-2 expression in only the MDA-MB-435-E1A stable transfectants. (a) Western blots of MDA-MB-231 and MDA-MB-435 cells treated with 0 or $40 \mu \mathrm{M}$ celecoxib for 5 days and tested for $\mathrm{COX}-2$ and $\mathrm{Bcl}-2$. Percentages indicate differences relative to the $0 \mu \mathrm{M}$ control samples. Protein expression was considered to be downregulated if the treated condition was at least $20 \%$ less than the control (untreated) condition. (b) Time course of Bcl-2 expression after treatment with 0 or $40 \mu \mathrm{M}$ celecoxib in MDA-MB-435-E1A and MDA-MB-231-E1A stable transfectants. Bcl-2 was suppressed at both 72 and $96 \mathrm{~h}$ in the MDA-MB-435-E1A stable transfectants but was not suppressed in the MDA-MB-231-E1A stable transfectants. (c) Transfection of MDAMB-435 cells with Bcl-2 DNA (+) or a control DNA (-) led to overexpression of Bcl-2 in all variants. (d) MDA-MB-435-E1A cells made to overexpress $\mathrm{Bcl}-2$ and non-Bcl-2-overexpressing cells were treated with 0 or $40 \mu \mathrm{M}$ celecoxib for 5 days, and cell viability was determined with a trypan-blue assay. $\mathrm{Bcl}-2$ overexpression did not restore sensitivity to celecoxib $(P=0.11)$.

apoptotic pathway. However, celecoxib-induced apoptosis did not depend on suppression of Bcl-2.

With regard to suppression of $\mathrm{Bcl}-2$ by $\mathrm{COX}-2$ inhibitors, some previous studies have shown that the ability of COX-2 inhibitors to induce apoptosis in cancer cells depends on the downregulation of Bcl-2 [19-23]. However, others have reported that COX-2 inhibitors can induce apoptosis in cancer cells independently of Bcl-2 [29,32]. Cao and Prescott [33] proposed that $\mathrm{Bcl}-2$ overexpression is probably caused by reductions in arachidonic acid and increases in $\mathrm{PGE}_{2}$ levels.
Nevertheless, our finding that COX-2 suppression did not suppress $\mathrm{Bcl}-2$ leads us to propose that other mechanisms exist by which celecoxib induces apoptosis, at least in the breast cancer cell lines we tested. In other words, it is unclear how much suppression of $\mathrm{Bcl}-2$ is enough to induce significant apoptosis, or, indeed, if celecoxib has the capacity to downregulate $\mathrm{Bcl}-2$. It is possible that only the reduction in $\mathrm{Bcl}-2$ led to apoptosis in the MDA-MB-435-E1A stable transfectants; however, that reduction would have to have been substantial. We showed that $40 \mu \mathrm{M}$ of celecoxib was enough to enhance E1A-induced apoptosis in MDA-MB-231-E1A and MDA-MB- 
MDA-MB-231-E1A

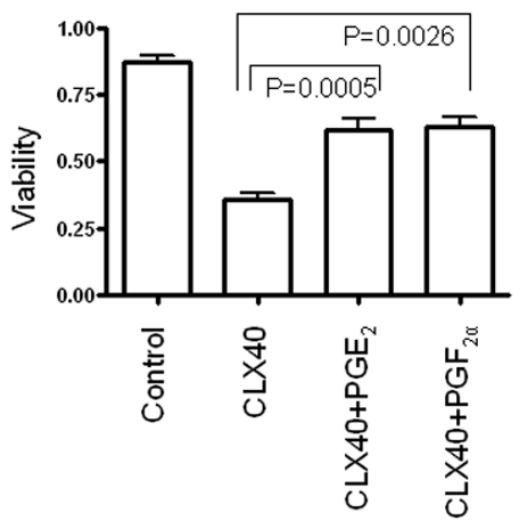

MDA-MB-435-E1A

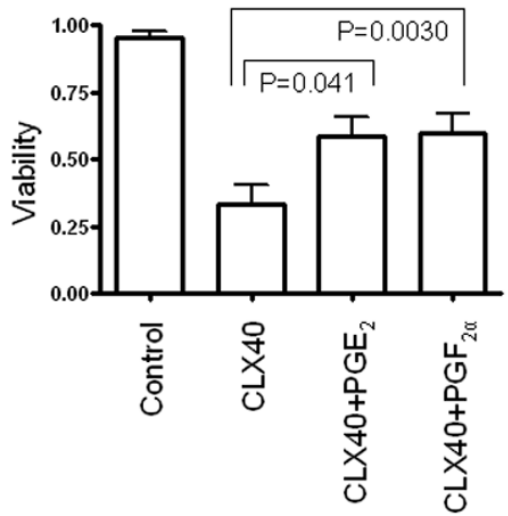

Celecoxib-induced apoptosis of MDA-MB-231-E1A and MDA-MB-435-E1A cells depends on PGE or PGF $_{2 \alpha}$. Treatment of MDA-MB-231-E1A and MDA-MB-435-E1A stable transfectants with 0 or $40 \mu \mathrm{M}$ celecoxib (CLX) plus $10 \mu \mathrm{M}$ of either PGE or PGF $_{2 \alpha}$ for 5 days blunted sensitivity to celecoxib in both cell lines.

435-E1A stable transfectants regardless of $\mathrm{Bcl}-2$ suppression. This result suggests that other molecules than $\mathrm{Bcl}-2$ could be critical for celecoxib to enhance E1A-induced apoptosis.

We then investigated the involvement of $\mathrm{PGE}_{2}$ or $\mathrm{PGF}_{2 \alpha}$, two molecules located downstream of COX-2. The synthesis of prostaglandins is known to depend on COX-2 activity. In one study, the synthesis of $\mathrm{PGE}_{2}$ or $\mathrm{PGF}_{2 \alpha}$ was enhanced by the overexpression of COX-2 in the mammary glands of COX-2 transgenic mice [34]. In addition, $\mathrm{PGF}_{2 \alpha}$ has been shown to promote tumorigenesis in endometrial cancer cells [35]. Several reports indicate that the reduction of COX-2 inhibits the release of prostaglandins. For example, treatment of the COX-2-overexpressing myeloma cell line ARH-77 with indomethacin led to the reduction of $\mathrm{PGD}_{2}, \mathrm{PGE}_{2}$, and $\mathrm{PGF}_{2 \alpha}$ [36]. Celecoxib has been shown to inhibit the release of $P G E_{2}$ or PGF $_{2 \alpha}$ from ureteral segments in swine [37]. NS-398 inhibited the production of prostaglandins, including $P \mathrm{PD}_{2}, \mathrm{PGE}_{2}$ and $\mathrm{PGF}_{2 \alpha}$, in the prostate cancer cell line PC-3 [38]. We speculate that both $\mathrm{PGE}_{2}$ and $\mathrm{PGF}_{2 \alpha}$ derived from COX-2 could be key factors in modulating the apoptotic effect in $E 1 A$ transfected cell lines. Indeed, we found that blocking $\mathrm{PGE}_{2}$ and $\mathrm{PGF}_{2 \alpha}$ production was crucial for celecoxib-induced apoptosis in the $E 1 A$ stable transfectants. We confirmed here that both $\mathrm{PGE}_{2}$ and $\mathrm{PGF}_{2 \alpha}$ influenced apoptosis, but celecoxib suppressed different prostaglandins in the two different cell lines. This difference could reflect the involvement of other pathways that modulate apoptosis in E1A-transfected cell lines.

Davis et al. [39] reported that the COX-2 inhibitor NS-398 was more cytotoxic in a prostate epithelial cell line in which $\mathrm{E} 2 \mathrm{~F} 1$ had been activated than in the original prostate epithelial cell lines, speculating that the reason for the greater cytotoxicity was a disruption in the retinoblastoma/E2F complexes. We showed that caspase- 9 and PARP were activated, but caspase-8 was not activated, in celecoxib-treated MDA-MB-231E1A and MDA-MB-435-E1A stable transfectants (Figure $3 B$ ). These findings are consistent with others showing that celecoxib enhances caspase-3 or caspase- 9 activation through $\mathrm{PGE}_{2}$ inhibition $[42,43]$. We speculate that $\mathrm{PGE}_{2}$ or $\mathrm{PGF}_{2 \alpha}$ (or both) inhibit intrinsic apoptotic pathway induced by $E 1 A$. This speculation is, to the best of our knowledge, the first to link $\mathrm{PGE}_{2}$ or $\mathrm{PGF}_{2 \alpha}$ in the apoptosis associated with E1A.

Generally speaking, COX-2 inhibitors, including celecoxib, are thought to block prostaglandin synthesis by inhibiting the enzymatic activity of COX-2. However, COX-2 inhibitors (including celecoxib) might also act by suppressing production of the COX-2 protein $[31,44,45]$. We showed that the celecoxib-sensitive MDA-MB-231-E1A and MDA-MB-435$E 1 A$ stable transfectants originally overexpressed COX-2, and they produced less COX-2 protein in the presence of celecoxib (Figures 1 and 4A). Our finding that COX-2 levels were highest in the MDA-MB-231-E1A cells was confirmed by others' reports that the MDA-MB-231 cell line expresses high levels of COX-2 [46-48]. Moreover, our findings regarding sensitivity to celecoxib imply that celecoxib inhibited the production of prostaglandins not only by inhibiting COX-2 enzymatic activity but also by modulating COX-2 protein expression. A previous report indicated that modulating COX2 protein expression with a structural analog of celecoxib (sc236) or with the pharmacologic COX-2 protein-suppressing agent curcumin affected apoptosis in the COX-2-positive colon cancer cell line HT-29 [49]; another report showed that modulating COX-2 protein expression with the retinoid $X$ receptor-selective retinoid $L G D 1069$ decreased $\mathrm{PGE}_{2}$ pro- 
duction in normal human mammary epithelial cells [50]. We speculate that the modulation of COX-2 protein expression by celecoxib is a significant part of its effect in reducing prostaglandin levels.

Our study had some limitations. For one thing, although we did confirm that all four E1A stable transfectants expressed $\mathrm{E} 1 \mathrm{~A}$ (Figure 1), the level of expression was not uniform among the cell lines. Specifically, MDA-MB-231-E1A cells expressed slightly more $\mathrm{E} 1 \mathrm{~A}$ than the other three cell lines, a result that has also been shown by others $[15,28]$. Thus, we were not able to exclude the possibility that E1A expression level could affect sensitivity to celecoxib. In addition, we examined only one COX-2 inhibitor, celecoxib. COX-2 inhibitors other than celecoxib can downregulate Bcl-2 [19,22]; whether other COX-2 inhibitors would downregulate Bcl-2 expression to a greater extent than celecoxib remains to be seen. Elucidation of the precise mechanism by which COX-2 inhibitors downregulate $\mathrm{Bcl}-2$ will help to clarify the appropriate uses of $\mathrm{COX}$ 2 inhibitors in preclinical settings for treating cancer.

\section{Conclusion}

We found that celecoxib enhanced E1A-induced apoptosis in breast cancer cells that express high levels of COX-2 protein and that this effect depended, at least in part, on blocking the production of $\mathrm{PGE}_{2}$ or $\mathrm{PGF}_{2 \alpha}$. Further studies exploring the precise mechanism by which prostaglandins influence $E 1 A$ induced apoptosis, and confirmation of synergistic effects between E1A gene therapy and COX-2 inhibitor treatment in cancer xenograft models, are needed to establish conclusively that COX-2 inhibitors can overcome resistance to $E 1 A$ induced apoptosis.

\section{Competing interests}

The authors declare that they have no competing interests.

\section{Authors' contributions}

TS participated in conceiving and designing the study, carried out many of the experiments, and drafted the manuscript. CB participated in the collection, analysis, and interpretation of findings, provided procedural guidance and expertise, and participated in revising the manuscript. AMT, an expert in COX and COX inhibition in cancer, conceived the prostaglandin experiments. NTU led the conception and design of the study, the analysis and interpretation of the findings, and the revisions to the manuscript. All authors read and approved the final manuscript.

\section{Acknowledgements}

We thank Dr Uma Raju for technical support and reagents, Dr Mien-Chie Hung for the E1A transfectants and assistance with the Bcl-2 transfections, and Christine F Wogan at the Department of Scientific Publications at M D Anderson Cancer Center for editorial suggestions. No grant funding supported this study.

\section{References}

1. Xing X, Yujiao Chang J, Hung M: Preclinical and clinical study of HER-2/neu-targeting cancer gene therapy. Adv Drug Deliv Rev 1998, 30:219-227.

2. Hortobagyi GN, Ueno NT, Xia W, Zhang S, Wolf JK, Putnam JB Weiden PL, Willey JS, Carey M, Branham DL, et al.: Cationic liposome-mediated E1A gene transfer to human breast and ovarian cancer cells and its biologic effects: a phase I clinical trial. $J$ Clin Oncol 2001, 19:3422-3433.

3. Villaret D, Glisson B, Kenady D, Hanna E, Carey M, Gleich L, Yoo $\mathrm{GH}$, Futran N, Hung MC, Anklesaria $\mathrm{P}$, et al.: A multicenter phase II study of $\operatorname{tgDCC}-\mathrm{E} 1 \mathrm{~A}$ for the intratumoral treatment of patients with recurrent head and neck squamous cell carcinoma. Head Neck 2002, 24:661-669.

4. Frisch SM, Mymryk JS: Adenovirus-5 E1A: paradox and paradigm. Nat Rev Mol Cell Biol 2002, 3:441-452.

5. Berk AJ: Recent lessons in gene expression, cell cycle control, and cell biology from adenovirus. Oncogene 2005, 24:7673-7685.

6. Gomez-Manzano C, Yung WK, Alemany R, Fueyo J: Genetically modified adenoviruses against gliomas: from bench to bedside. Neurology 2004, 63:418-426.

7. Trimarchi JM, Lees JA: Sibling rivalry in the E2F family. Nat Rev Mol Cell Biol 2002, 3:11-20.

8. Evan GI, Vousden KH: Proliferation, cell cycle and apoptosis in cancer. Nature 2001, 411:342-348.

9. Wu X, Levine AJ: p53 and E2F-1 cooperate to mediate apoptosis. Proc Natl Acad Sci USA 1994, 91:3602-3606.

10. Teodoro JG, Shore GC, Branton PE: Adenovirus E1A proteins induce apoptosis by both p53-dependent and p53-independent mechanisms. Oncogene 1995, 11:467-474.

11. Chen MJ, Holskin B, Strickler J, Gorniak J, Clark MA, Johnson PJ, Mitcho M, Shalloway D: Induction by E1A oncogene expression of cellular susceptibility to lysis by TNF. Nature 1987, 330:581-583.

12. Duerksen-Hughes P, Wold WS, Gooding LR: Adenovirus E1A renders infected cells sensitive to cytolysis by tumor necrosis factor. J Immunol 1989, 143:4193-4200.

13. Routes JM, Ryan S, Clase A, Miura T, Kuhl A, Potter TA, Cook JL: Adenovirus E1A oncogene expression in tumor cells enhances killing by TNF-related apoptosis-inducing ligand (TRAIL). J Immunol 2000, 165:4522-4527.

14. Shao R, Lee DF, Wen $Y$, Ding $Y$, Xia W, Ping B, Yagita $H$, Spohn $B$, Hung MC: E1A sensitizes cancer cells to TRAIL-induced apoptosis through enhancement of caspase activation. Mol Cancer Res 2005, 3:219-226.

15. Liao $Y$, Hung MC: Regulation of the activity of p38 mitogenactivated protein kinase by Akt in cancer and adenoviral protein E1A-mediated sensitization to apoptosis. Mol Cell Biol 2003, 23:6836-6848.

16. Shao R, Karunagaran D, Zhou BP, Li K, Lo SS, Deng J, Chiao P, Hung MC: Inhibition of nuclear factor-kappaB activity is involved in E1A-mediated sensitization of radiation-induced apoptosis. J Biol Chem 1997, 272:32739-32742.

17. Lee WP, Liao Y, Robinson D, Kung HJ, Liu ET, Hung MC: Axl-gas6 interaction counteracts E1A-mediated cell growth suppression and proapoptotic activity. Mol Cell Biol 1999, 19:8075-8082.

18. Bartholomeusz C, Itamochi H, Yuan LX, Esteva FJ, Wood CG, Terakawa N, Hung MC, Ueno NT: Bcl-2 antisense oligonucleotide overcomes resistance to E1A gene therapy in a low HER2expressing ovarian cancer xenograft model. Cancer Res 2005, 65:8406-8413.

19. Liu XH, Yao S, Kirschenbaum A, Levine AC: NS398, a selective cyclooxygenase-2 inhibitor, induces apoptosis and down-regulates bcl-2 expression in LNCaP cells. Cancer Res 1998, 58:4245-4249.

20. Subhashini J, Mahipal SV, Reddanna P: Anti-proliferative and apoptotic effects of celecoxib on human chronic myeloid leukemia in vitro. Cancer Lett 2005, 224:31-43.

21. Catalano A, Graciotti L, Rinaldi L, Raffaelli G, Rodilossi S, Betta $P$ Gianni W, Amoroso S, Procopio A: Preclinical evaluation of the nonsteroidal anti-inflammatory agent celecoxib on malignant mesothelioma chemoprevention. Int J Cancer 2004, 109:322-328. 
22. Li XH, Li JJ, Zhang HW, Sun P, Zhang YL, Cai SH, Ren XD: Nimesulide inhibits tumor growth in mice implanted hepatoma: overexpression of Bax over Bcl-2. Acta Pharmacol Sin 2003, 24:1045-1050.

23. Basu GD, Pathangey LB, Tinder TL, Lagioia M, Gendler SJ, Mukherjee $P$ : Cyclooxygenase-2 inhibitor induces apoptosis in breast cancer cells in an in vivo model of spontaneous metastatic breast cancer. Mol Cancer Res 2004, 2:632-642.

24. Pereg $D$, Lishner $M$ : Non-steroidal anti-inflammatory drugs for the prevention and treatment of cancer. J Intern Med 2005, 258:115-123

25. Tsujii M, DuBois RN: Alterations in cellular adhesion and apoptosis in epithelial cells overexpressing prostaglandin endoperoxide synthase 2. Cell 1995, 83:493-501.

26. Sheng H, Shao J, Morrow JD, Beauchamp RD, DuBois RN: Modulation of apoptosis and $\mathrm{Bcl}-2$ expression by prostaglandin $\mathrm{E2}$ in human colon cancer cells. Cancer Res 1998, 58:362-366.

27. Shao R, Hu MC, Zhou BP, Lin SY, Chiao PJ, von Lindern RH, Spohn B, Hung MC: E1A sensitizes cells to tumor necrosis factor-induced apoptosis through inhibition of IkappaB kinases and nuclear factor kappaB activities. J Biol Chem 1999, 274:21495-21498.

28. Meric F, Liao Y, Lee WP, Pollock RE, Hung MC: Adenovirus $\mathbf{5}$ early region $1 \mathrm{~A}$ does not induce expression of the ewing sarcoma fusion product EWS-FLI1 in breast and ovarian cancer cell lines. Clin Cancer Res 2000, 6:3832-3836.

29. Kern MA, Schubert D, Sahi D, Schoneweiss MM, Moll I, Haugg AM, Dienes HP, Breuhahn K, Schirmacher P: Proapoptotic and antiproliferative potential of selective cyclooxygenase-2 inhibitors in human liver tumor cells. Hepatology 2002, 36:885-894.

30. Zou Y, Peng H, Zhou B, Wen Y, Wang SC, Tsai EM, Hung MC: Systemic tumor suppression by the proapoptotic gene bik. Cancer Res 2002, 62:8-12.

31. Tuynman JB, Peppelenbosch MP, Richel DJ: COX-2 inhibition as a tool to treat and prevent colorectal cancer. Crit Rev Oncol Hematol 2004, 52:81-101.

32. Hsu AL, Ching TT, Wang DS, Song X, Rangnekar VM, Chen CS: The cyclooxygenase-2 inhibitor celecoxib induces apoptosis by blocking Akt activation in human prostate cancer cells independently of Bcl-2. J Biol Chem 2000, 275:11397-11403.

33. Cao $\mathrm{Y}$, Prescott SM: Many actions of cyclooxygenase-2 in cellular dynamics and in cancer. J Cell Physiol 2002, 190:279-286.

34. Liu CH, Chang SH, Narko K, Trifan OC, Wu MT, Smith E, Haudenschild C, Lane TF, Hla T: Overexpression of cyclooxygenase-2 is sufficient to induce tumorigenesis in transgenic mice. $J$ Biol Chem 2001, 276:18563-18569.

35. Jabbour HN, Sales KJ, Boddy SC, Anderson RA, Williams AR: A positive feedback loop that regulates cyclooxygenase-2 expression and prostaglandin F2 $\alpha$ synthesis via the F-seriesprostanoid receptor and extracellular signal-regulated kinase 1/2 signaling pathway. Endocrinology 2005, 146:4657-4664.

36. Ding J, Tsuboi K, Hoshikawa H, Goto R, Mori N, Katsukawa M, Hirai E, Yamamoto S, Abe M, Ueda N: Cyclooxygenase isozymes are expressed in human myeloma cells but not involved in anti-proliferative effect of cyclooxygenase inhibitors. Mol Carcino 2006, 45:250-259.

37. Jerde TJ, Calamon-Dixon JL, Bjorling DE, Nakada SY: Celecoxib inhibits ureteral contractility and prostanoid release. Urology 2005, 65:185-190.

38. Nithipatikom K, Isbell MA, Lindholm PF, Kajdacsy-Balla A, Kaul S, Campell WB: Requirement of cyclooxygenase-2 expression and prostaglandins for human prostate cancer cell invasion. Clin Exp Metastasis 2002, 19:593-601.

39. Davis JN, McCabe MT, Hayward SW, Park JM, Day ML: Disruption of $\mathrm{Rb} / \mathrm{E} 2 \mathrm{~F}$ pathway results in increased cyclooxygenase2 expression and activity in prostate epithelial cells. Cancer Res 2005, 65:3633-3642.

40. Nevins JR: The Rb/E2F pathway and cancer. Hum Mol Genet 2001, 10:699-703.

41. Tsantoulis PK, Gorgoulis VG: Involvement of E2F transcription factor family in cancer. Eur J Cancer 2005, 41:2403-2414.

42. Dandekar DS, Lopez M, Carey RI, Lokeshwar BL: Cyclooxygenase-2 inhibitor celecoxib augments chemotherapeutic druginduced apoptosis by enhancing activation of caspase-3 and 9 in prostate cancer cells. Int J Cancer 2005, 115:484-492.
43. Zhang Z, Lai GH, Sirica AE: Celecoxib-induced apoptosis in rat cholangiocarcinoma cells mediated by Akt inactivation and Bax translocation. Hepatology 2004, 39:1028-1037.

44. Narayanan BA, Condon MS, Bosland MC, Narayanan NK, Reddy BS: Suppression of $\mathrm{N}$-methyl-N-nitrosourea/testosteroneinduced rat prostate cancer growth by celecoxib: effects on cyclooxygenase-2, cell cycle regulation, and apoptosis mechanism(s). Clin Cancer Res 2003, 9:3503-3513.

45. Yao M, Kargman S, Lam EC, Kelly CR, Zheng Y, Luk P, Kwong E, Evans JF, Wolfe MM: Inhibition of cyclooxygenase-2 by rofecoxib attenuates the growth and metastatic potential of colorectal carcinoma in mice. Cancer Res 2003, 63:586-592.

46. Basu GD, Pathangey LB, Tinder TL, Gendler SJ, Mukherjee P: Mechanisms underlying the growth inhibitory effects of the cyclo-oxygenase-2 inhibitor celecoxib in human breast cancer cells. Breast Cancer Res 2005, 7:422-435.

47. Liu XH, Rose DP: Differential expression and regulation of cyclooxygenase- 1 and -2 in two human breast cancer cell lines. Cancer Res 1996, 56:5125-5127.

48. Timoshenko AV, Xu G, Chakrabarti S, Lala PK, Chakraborty C: Role of prostaglandin $E 2$ receptors in migration of murine and human breast cancer cells. Exp Cell Res 2003, 289:265-274

49. Agarwal B, Swaroop P, Protiva P, Raj SV, Shirin H, Holt PR: Cox2 is needed but not sufficient for apoptosis induced by Cox-2 selective inhibitors in colon cancer cells. Apoptosis 2003, 8:649-654

50. Kong G, Kim HT, Wu K, DeNardo D, Hilsenbeck SG, Xu XC, Lamph WW, Bissonnette R, Dannenberg AJ, Brown PH: The retinoid $X$ receptor-selective retinoid, LGD down-regulates cyclooxygenase-2 expression in human breast cells through transcription factor crosstalk: implications for molecularbased chemoprevention. Cancer Res 1069, 65:3462-3469. 